\title{
Op soek na die kontoere vir 'n teologies-etiese begronding van homoseksualiteit: 'n Gereformeerde perspektief
}

\author{
Compaan, Auke \\ University of Pretoria \\ auke.compaan.ac@gmail.com
}

\begin{abstract}
In search of the contours of theological ethics of human sexuality with regard to homosexuality: a Reformed perspective

This article offers a description and discussion of the contours of theological ethics of human sexuality, with regard to homosexuality. In the first part of the article, the topic of homosexuality is discussed within the larger historical development of the concept of human nature in the broader tradition of the church. Here special attention is paid to the views of Philo of Alexandria, St. Augustine and St. Aquinas, showing that the right and wrong of the sexual act were judged in terms of the procreative potential of the act. In the second part of the article, I propose a reformed perspective with regard to sexual ethics. This is done by a re-reading of the concept of human nature, by removing it from the traditional Roman Catholic "nature-grace" paradigm of salvation and re-reading it in terms of the reformed paradigm of "creation (law)-singospel". I argue that behind this paradigm shift, there is a movement from an ontology of being to an ontology of relationality and that this implies a move from procreation as the foundation of sexual ethics to the seeking of erotic justice in all our intimate relationships as a basis for sexual ethics.
\end{abstract}

Key words

Ethics; homosexuality; human nature; Reformed; justice

\section{Inleiding}

Die artikel wil aantoon dat die manier waarop die kerk menslike seksualiteit vir eeue verstaan het, ten nouste verweef is met 'n bepaalde verstaan van menslike natuur, wat weer ingebed was in die Middeleeuse skolastiese natuur-genade skema. Binne hierdie paradigma, wat 'n hoogtepunt bereik 
in die denke van Thomas Aquinas, is menslike natuur as manlik verstaan. Hierdie patriargale manlike verstaan van "menslike natuur" het nie alleen vir eeue vroue onderdruk nie, maar ook daartoe gelei dat'n verskynsel soos homoseksualiteit "as teen-natuurlik" gedink is. Hier word gefokus op die bydraes van Philo van Alexandrië, Augustinus en veral Aquinas met sy teleologiese Aristoteliaanse etiek, om die ontwikkeling van die klassieke kerklike paradigma te verhelder.

Ek wil argumenteer dat die Reformasie met die ontologie van die RoomsKatolieke Kerk breek. Die Reformasie berus op 'n wet-sonde-evangelie paradigma, wat 'n ander relasionele ontologie tot stand bring en myns insiens 'n nuwe begronding vir seksuele etiek moontlik maak. Die ontologiese breuk wat die Reformasie aankondig, beteken 'n verskuiwing van 'n essensialistiese benadering in die etiek na 'n relasionele benadering. In terme van seksualiteit impliseer dit dat ons seksuele etiek nie langer definieer in terme van biologie en prokreasie nie, maar eerder as die soeke na geregtigheid in al ons verhoudings - van die mees intieme verhoudings tot die omvattendste politieke magskonstellasies. My voorstel is dat ons ons etiek van menslike seksualiteit nie probeer aflees uit Bybelverse of historiese praktyke nie, maar vanuit ons diepste teologiese identiteit dink en dat seksuele etiek in ons tyd 'n soeke word na erotiese geregtigheid, sonder dat daar aan etiese relativisme toegegee word. Seksuele etiek wat onderlê word deur 'n soeke na geregtigheid, maak dit vir die kerk moontlik om 'n pluraliteit van gendergroepe, (LGBTQI) te akkommodeer, sonder om praktyke soos pedofilie te legitimeer.

\section{Die ontwikkeling van die tradisionele kerklike paradigma vir seksuele etiek}

Wie ook al na die historiese wortels van die tradisionele beskouing van seksualiteit vra, ontdek gou dat dit deurstoot na die historiese verstaan van die konsepte menslike natuur ${ }^{1}$ en die passies of begeertes van die liggaam. $\mathrm{Na}$ die tyd van die Nuwe Testament is die konsep menslike natuur steeds binne 'n antieke patriargale en androgene beskouing van menswees gegiet. ${ }^{2}$

1 Vir 'n oorsig oor die klassieke natuur-kultuur debat sien Naphy, W (2006) Born to be Gay: a history of homosexuality, pp.77- 130.

2 Vir 'n relativering van 'n androgene beskouing van seksualiteit, sien Cortez, M. (2010) se hoofstuk Sexuality in sy boek, Theological Anthropology - a Guide for the Perplexed, 
'n Androgene beskouing van menswees werk met die veronderstelling dat daar iets soos 'n algemene menslike natuur is waaraan alle mense deel en dat seksualiteit nie tot die basiese van menswees behoort nie. Die eintlike probleem hiermee is dat menslike natuur, binne 'n patriargale kultuur outomaties as manlik verstaan is. Manwees was normatief vir menswees. ${ }^{3}$ Soos Simone de Beauvoir tereg opmerk: "Man is defined as a human being and a woman as female - whenever she behaves as a human being she is said to imitate the male" (in Cortez 2010:50). Die androgene ideaal vir menswees het verder nie net patriargie as vanselfsprekend bevestig nie, maar ook die betekenis van die liggaam en liggaamlikheid in seksualiteit misken. Hierdie verstaan van seksualiteit word vandag ten sterkte afgewys (Cortez 2010:44-46).

Binne 'n patriargale kultuur word die vrou as 'n besitting van haar man gedefinieer en word haar belangrikste doel diévan prokreasie. Teoloëhet met ander woorde die eerste vyf eeue die kulturele seksisme van hul patriargale wêreld in 'n teologiese antropologie opgeneem. Ek wil graag aantoon dat hierdie verstaan van menslike natuur, aanleiding gee tot die verstaan van prokreasie (binne die huwelik) as die eintlike betekenis van seksualiteit. Hierdie benadering tot seksualiteit word tot vandag toe in die RoomsKatolieke kerk se belangrikste dokumente rondom seksualiteit gereflekteer (vgl. Humanae vitae 1968 en Veritas Splendor 1993) ${ }^{4}$. Ons moet ook daarop let dat die Rooms-Katolieke Kerk se afwysing van homoseksualiteit as intrinsiek boos, op dieselfde etiese gronde vir morele of immorele seks binne die huwelik, berus. Indien moreel aanvaarbare seks alleen binne die raamwerk van prokreasie gesien word, kan selfdegeslagverhoudings niks anders as immoreel wees nie (Salzman \&Lawler 2012:7-11).

Die patriargale androgene beskouing van menswees en gepaardgaande beskouing van seksualiteit en gender, hang ook saam met die vroeë kerk se verstaan van begeerte en die liggaam. Die Joods-Christelike tradisie is

pp. 41-67.

3 Ons sien hoe vanselfsprekend 'n seksistiese patriargie vir die vroeë kerkvaders was in Irenaeus wat byvoorbeeld skryf: "Having become disobedient, Eve was made to cause death, both to herself and to the entire human race." Ambrosuis skryf dat: "Eve was first to be deceived and was responsible for deceiving the man." Chrysostomus was meer blatant: "The woman taught once, and ruined all." (Wiley 2010:109).

4 Sien Wiley, R. (2010) Humane vitae, Sexual Ethics, and the Roman Catholic Church, pp. 99-114. 
ironies genoeg nie vyandig teenoor begeerte nie, maar kultiveer dit ten diepste. Dink aan 'n boek soos Hooglied wat oorvloei van erotiese energie, of later Augustinus se Belydenisse (Confessions). Begeerte is deel van JoodsChristelike gelowiges se aanbidding van God. In die teologiese nadenke van iemand soos Gregorius van Nissa (Coakley 2012:52) en Augustinus (Lootens 2012:68) staan begeerte voorop. Ons verhouding met God is 'n erotiese verhouding. Ons begeer God. Ons verlang na eenheid met God. Vir Augustinus is sonde dan juis wanneer ons begeerte na God misloop. So is ook die liggaam van die begin af deel van die Christelike aanbidding van God. Moderne gelowiges moet die kerkvaders en veral Augustinus van harte bedank dat hulle, met die uitwerk van die opvatting dat God mens geword het in Jesus van Nasaret, 'n siening wat ook deur die kerklike konsilies van die $4{ }^{\text {de }}$ eeu as Ortodoks bevestig is, 'n radikaal nuwe beskouing van die menslike liggaam teweeg gebring het. In stryd met die Doketisme en die Manicheïsme, wat die materiële werklikheid as boos beskou het, het die eerste kerkvaders, vasgestaan dat die "Seun" geïnkarneer is in 'n menslike liggaam.

Die liggaam was dus van die begin af geweldig belangrik in die Christelike geloof. Dit was deel van "om gered" te wees, maar die kerk kon vir baie eeue nooit die vreugde en plesier van liggaamlikheid en seksualiteit omhels nie (Kamitsuka 2010:2). Die vroeë kerk se verhouding met die liggaam was en is vandag steeds ambivalent. Ons sien hierdie ambivalensie daarin dat die sakramente, (die doop en nagmaal), die oplê van hande en begrafnisrituele, enersyds om die liggaam sentreer, terwyl toenemende askese, veral met die opkoms van die monastisisme in die $4^{\text {de }}$ eeu, die kerk toenemend afwysend teenoor die liggaam gestaan het. Die liggaam is nodig vir 'n lewe van toewyding aan God, maar die liggaam met sy passies en neiging tot sonde, staan teenoor hoër geestelike aspirasies. In die antieke wêreld, is die liggaam primêr met vroue identifiseer. In 'n androgene gender antropologie, dit wil sê 'n mangesentreede verstaan van menswees, is die hoër kapasiteite van menswees (denke) verbind met die man en die laer kapasiteite (liggaam) met vrou (Wiley 2010:111).

Ons sien reeds vroeg in die Christelike teologie by iemand soos Philo van Alexandrië (25 v.C. - 40 n.C.) hoe 'n androgene gender antropologie, gekombineer met die strewe na 'n spiritualiteit wat afwysend staan teenoor die liggaam en begeerte, aanleiding gee tot 'n baie negatiewe beskouing 
van seksualiteit. Philo het as Neo-Platonis die siel bo die liggaam verhef en dit gekombineer met die reinheidswette van die Pentateug. Philo prys maagdelikheid by mans en vrouens as absoluut noodsaaklik in die soeke na God en die ontwikkeling van die siel. Dit is waarskynlik Philo se denke wat gelei het tot die idee dat Maria se maagdelikheid die simbool is van haar reinheid en haar nabyheid aan God (Vardy 2009:49).

Vir Philo was dit voor die handliggend dat seksualiteit afgestem is op prokreasie, ook binne die huwelik. Hy het mans wat seks met hulle vroue in 'n tyd van onvrugbaarheid (menstruasie) gehad het, of seks met vroue wat bekend was dat hulle onvrugbaar was, veroordeel. Iemand wat, behalwe vir prokreasie, deel in seksuele aktiwiteite is nie 'n goeie voorbeeld van 'n perfekte lewe voor God nie. Hy het volgehou dat God "should converse with the truely virgin nature" (Vardy 2009:50). Dit is daarom gepas om Maria te sien as 'n rein en heilige vrou wat geen seksuele omgang gehad het nie. Die siel wat God werklik soek is die siel wat maagdelikheid beoefen. Fisiese maagdelikheid is beskou as bewys van geestelike maagdelikheid en daarom prys Philo ouer vroue wat kies om nie te trou nie.

Die geweldige kritiek op Augustinus se bydrae tot die Christelike tradisie is my insiens oordrewe ${ }^{5}$, maar die Christelike kerk moet erken dat hy groot foute gemaak het en dat sy bydrae tot morele onderrig oor seksualiteit die kerk se denke vir 16 eeue negatief beïnvloed het. Die konteks vir sy bespreking van seks en die huwelik was natuurlik die oersonde van Adam en Eva (original sin). Hy sien Adam se sonde as 'n mislukking aan die begin

5 Die Katolieke Duitse vroue teoloog, Uta Ranke-Heinemann het byvoorbeeld in 1991 'n boek gepubliseer met die titel: Eunuchs for the Kingdom of Heaven, women sexuality and the Catholic Church waarin sy'n dramatiese analise doen van Augustinus se idees rondom die huwelik en seksualiteit. Sy skryf: "The man who fused Christianity together with hatred of sex and pleasure into a systematic unity was the greatest of the Church Fathers, St. Augustine." (75). "Like many neurotics he radically separates love and sexuality." (76). "Augustine was the father of a fifteen-hundred-year-long anxiety about sex and an enduring hostility to it." "The attitude of the Church $s$ celibate hierarchy is that the locus par excellence of sin is sex, a view based on Augustiness pleasurehating fantasies." (90). Hierdie oordele is myns insiens oordryf en eensydig. Ons moet Augustinus se verstaan van seksualiteit nie losmaak van sy eie verhaal nie. Augustinus (2004) beskryf homself as 'n slaaf van sy seksuele impulse. Sy taal in die Confessions, om seksualiteit te beskryf is egter deurgaans negatief. Hy gebruik taal soos: siekte, wanorde, korrupsie; begeerte is modder $(2.2,3.1)$, 'n maalkolk $(2.2)$, kettings $(2.2,3.1)$ dorings (2.3), a gapende afgrond (3.1), 'n oop seer wat gekrap moet word (3.1). Die taal moet gesien word binne Augustinus se stryd met sy eie wil teenoor die wil van God. 
van die geskiedenis, spesifiek as 'n mislukking om gehoorsaam te wees. Die straf vir hierdie oersonde (original sin) was wanorde, wat spesifiek in skeefgetrekte seksuele begeerte (concupiscence) manifesteer - wat in die menslike natuur ervaar en beleef word. Augustinus het geglo dat seksuele begeerte die gevolg is van die oersonde as gevolg van Adam en Eva se verbanning uit die paradys en dat dit van ouer na kind oorgedra word, deur die seksdaad (Wiley 2010:103).

Seksuele begeerte was vir Augustinus 'n kompulsie, 'n irrasionele impuls wat hy nie sonder God se hulp kon beheer nie. Die feit dat mans ereksies kry was vir hom 'n skande. Hierdie onvermoë om jou liggaam te beheer was vir hom 'n refleksie van die sondeval. Voor die sondeval sou geslagsdele rasioneel reageer het. Hy het volgehou dat die mens (man) voor die sondeval, volle beheer oor sy seksuele drange sou hê en dat prokreasie sou plaasvind sonder erotiese begeerte en suiwer op grond van die wil. Seksuele begeerte was vir hom die laaste hindernis na volkome oorgawe aan God (Vardy 2009:54). Ideaal gesproke is alle seks vir die doel van prokreasie, ook binne die huwelik. Augustinus het trou binne die huwelik geweldig beklemtoon. Dit het vir hom beteken dat elke party in die huwelik 'n plig het om die seksuele behoeftes van die ander te bevredig, en die vervulling van dié taak is nie as sonde beskou nie. Sy denke in die verband het 'n groot invloed op die Middeleeue uitgeoefen. Seks binne die huwelik is deurgaans in die Middeleeue gesien as medisyne, of geneesmiddel (remedy), teen sonde (Vardy 2009:55).

Die groot wins in Aquinas ${ }^{6}$ se denke is dat seksuele begeerte as natuurlik vir die mensheid beskou is en dat hy argumenteer vir die volheid van

6 Aquinas is baie meer positief oor die liggaam as wat ons van 'n Middeleeuse denker verwag. Die belangrikste faktor om Aquinas se intellektuele agtergrond te verstaan was die beskikbaarheid van nuwe filosofiese bronne, waarvan Aristoteles die belangrikste is. Aristoteles is veral belangrik vir Aquinas se verstaan van die liggaam. Hoewel Aquinas bekend was met die Platoniese verstaan van die siel, berus sy antroplogie grootliks op sy Aristoteliaanse verstaan van die mens as a "hylemorfiese" eenheid (Barnes 2010:86). Die mens is 'n eenheid saamgestel uit materie (Grieks hyle) en vorm (Grieks morphe). Aquinas het die siel as die substansiēle vorm van die liggaam beskou, bedoelende die siel skenk syn aan die liggaam, maar dit is ook afhanklik van die liggaam vir kennis en perfeksie. Omdat dele hul perfeksie vind in die geheel, is die siel sonder die liggaam, gebroke en onvolmaak. In kort: die hylemorfiese natuur van die mens heg hoë waarde aan die liggaam en liggaamlike passies. Die fakulteit van sensualiteit is natuurlik en nodig vir kennis en die oorlewing van die individu en spesie. Bygestaan deur oorspronklike geregtigheid in die oorspronklike staat van integriteit voor die sondeval, was die liggaam en die sensuele passies perfek georden in verhouding tot die siel en die 
seksuele plesier in die staat van oorspronklike integriteit (Barnes 2010:86). Aquinas se positiewe evaluering van seksuele begeerte, beteken nie 'n ongekwalifiseerde positiewe evaluering van seks en seksuele plesier nie. Die probleem is dat, as gevolg van die wanorde van die menslike natuur na die sondeval, onbehoorlike begeerte na seksuele plesier as 'n doel insigself beskou is. Vir Aquinas bly die liggaam, liggaamlike passies en seksuele genieting ondergeskik aan die siel se intellektuele genieting van God. Hierdie subordinering geld vir alle liggaamlike handelinge soos eet en drink. Die individu word bewaar en oorleef deur kos, en die menslike spesie deur seksuele reproduksie. In albei gevalle is die rasionele doel van die handeling oorlewing eerder as plesier. Eet en seks moet net beoefen word met die oog op rasionele doelwitte. Die doel van seks is reproduksie. Aquinas is deurgaans in sy werk helder op hierdie punt.

Aquinas volg grootliks Aristoteles se teleologiese benadering in sy seksuele etiek. Dit wat eties goed is, word bepaal deur die doel daarvan (Vardy 2009:61). Hy veronderstel ook 'n universele menslike natuur waarin alle mense noodwendig deel. As die doel van seks reproduksie is, is die doel van genitalieë tog ook 'n gegewe. Die konsekwensie hiervan is dat:

- Geen kunsmatige metodes van geboortebeperking gebruik kan word nie, omdat dit die doel van die seksuele handeling (wat reproduksie is) versteur.

- Masturbasie sonde is, omdat dit beteken genitalieë word gebruik vir 'n doel waarvoor dit nie bestem is nie.

- Homoseksualiteit, indien dit beoefen word, intrinsiek boos is, omdat genitalieë nie gebruik word waarvoor dit bestem is en die moontlikheid van prokreasie van die begin af uitgesluit is. Homoseksualiteit is daarom "teen die natuur". Verkragting is ook 'n minder ernstige sonde as masturbasie, want in die geval van verkragting word genitalieë ten minste vir hul oorspronklike doel gebruik (Vardy 2009:61).

Hierdie tipe etiek, wat tot vandag toe in die Rooms-Katolieke Kerk se belangrikste dokumente rondom seksualiteit reflekteer (vgl. Veritas Splendor, 1993) word, berus natuurlik op dit wat Aquinas beskryf het as 
natuurwet (Natural Law) (Wiley 2010:104). Natuurwet word verstaan as die rede se vermoë om te onderskei wat reg en toepaslik is vir die menslike natuur. Die Rooms-Katolieke Kerk deel in 'n lang tradisie met 'n bepaalde optimisme oor die menslike rede, hoewel dit deur die sondeval verduister is. 'n Dokument Human Vitae 1968, veronderstel dat die mens op 'n redelike wyse die wêreld verstaan wat God gemaak het, insluitende die menslike natuur as deel van hierdie wêreld. Die mens se morele beginsels is logies gewys ingebed in die natuur en afgelei van die doel van die natuur. Hierdie beginsels reflekteer God se plan vir die mens (Wiley 2010:104).

Die probleem is dat ons vandag, na Nietzsche, Marx, Freud en veral dan Foucault, weet dat dit wat vir ons vanselfsprekend lyk, dikwels gevorm is deur persoonlike en kulturele belange en voorveronderstellings, en dat die belange van 'n spesifieke groep of groepe gewoonlik versluierd en heimlik in stand gehou word. Die probleem met so 'n etiese benadering is byvoorbeeld dat manlike dominering tog vanselfsprekend gegee is in die ordening van die skepping. As dit as uitgangspunt geneem word, is vroue vanselfsprekend minder mens as mans, en is dit 'n klein sprong om van hier te veronderstel dat sekere sosiale, regs- en religieuse diskriminasie teen vroue geregverdig is. Die waarheidsopvatting onderliggend hieraan is dat die waarheid iewers "daarbuite" gegee is en dat ons dit bloot kan aflees.

'n Sterker punt van kritiek is dat in die algemene- en teologiese etiek rondom seksualiteit daar nie meer aanvaar word dat 'n handeling moreel of immoreel is op grond van die biologiese doelmatigheid daarvan nie (Wiley 2010:107). Aquinas het veronderstel dat die doel van dinge in die natuur gegee is en dat dit tot die kapasiteit van die rede behoort om dit te ontdek. Om die doeleindes van die natuur te verstaan, is terselfdertyd om God se wil vir die menslike natuur te verstaan. Handelinge wat konformeer met die doeleindes wat in die natuur gegee is, is moreel. Handelinge wat inmeng of bots met doeleindes wat in die natuur gegee is, is immoreel. Verder is dit eties problematies om morele beginsels van die liggaam self af te lei. Die prokreatiewe potensiaal van geslagsorgane dikteer hul morele gebruik in Aquinas se etiek, wat eties onhoudbaar geword het (Vardy 2009:62). Seksuele etiek wat só in die natuur begrond is, is myns insiens natuurlik heelwat nader aan die seksuele etiek van die Rooms-Katolieke Kerk as aan die grondslae van goeie Gereformeerde teologie. 
Die artikel wil'n beskrywing en bespreking van die kontoerevan'n teologiese etiek van menslike seksualiteit, met betrekking tot homoseksualiteit aanbied. In die eerste deel van die artikel is homoseksualiteit bespreek binne die breër historiese ontwikkeling van die konsep van menslike natuur in die kerklike tradisie. Hier is gewys op die perspektiewe van Philo, Augustinus en Aquinas. In die lig hiervan is argumenteer dat die reg en verkeerd van die seksuele daad beoordeel is in terme van die voortplantingspotensiaal van die daad. In die tweede deel van die artikel word 'n Gereformeerde perspektief met betrekking tot seksuele etiek voorgestel. Dit word gedoen deur die konsep van menslike natuur los te maak van die Rooms-Katolieke "natuur-genade" paradigma van verlossing, en 'n reïnterpretasie van die konsep in terme van 'n Gereformeerde paradigma van "skepping (wet)sonde-evangelie". Ek wil dus argumenteer dat, vanuit 'n Gereformeerde perspektief, daar daarom nie oor seksualiteit in terme van voortplanting en biologie gedink kan word nie. In die derde deel van die artikel word dan gevra hoe die uitleef van seksualiteit in die lig van 'n identiteit ín Christus en as deel van die liggaam van Christus verstaan kan word.

\section{Seksualiteit na die Reformasie}

Dit is onmoontlik om die moderne wêreld en hedendaagse sienings van seksualiteit en die huwelik te verstaan sonder om te let op die Reformasie se bydrae $e^{7}$. Hier kan Luther se skerp reaksie teen monastisisme en die selibaat as geestelike bewys van heiligmaking, veral ter sprake gebring word. Die probleem met die selibaat, het Luther geargumenteer, is dat die kerk die gewete van die gelowige bind deur 'n spesifieke praktyk die bewys te maak van heiligmaking (Capetz 2010:120-121). Die ideaal van selibaat het vir

7 Na die Reformasie van Pous Gregorius VII (1073-1085) is die huwelik in die Middeleeue voor die Reformasie op 'n drievoudige wyse beskou: 1) as a geskape natuurlike assosiasie, onderworpe aan die wetmatighede van die natuur; 2) 'n kontrak van konsensus onderworpe aan die algemene wette van 'n kontrak; 3) 'n sakrament van die geloof, onderworpe aan die wette van die kerk. Die huwelik as natuurlik geskape assosiasie is gesien as 'n plig vir gesondes en 'n genesing vir die siekes. Die meeste middeleeuse skrywers, volg Paulus se raad in 1 Kor.7 dat selibate kontemplasie bo die natuurlike dryf na seksuele eenwording gestel moet word. Na die sondeval bly die huwelik 'n plig, maar net vir hulle wat die versoeking van seksuele sonde beleef. Vir die wat nie so versoek word nie, is die huwelik 'n minderwaardige opsie. Dit was meer deugsaam om die geestelike lewe van selibaat en kontemplasie te bewandel, as die temporele lewe van huwelik en gesin (Witte \& Kingdon 2005: Kindle location:654). 
Luther en Calvyn geen plek in 'n reformatoriese teologiese raamwerk nie. Die huwelik word die hoogste ideaal.

In teenstelling met reformatore soos Wycliffe en Hus wat hul kritiek op die Katolieke Kerk gerig het op die morele sondes van die pous en kerklikes, het dit vir Luther gegaan oor die fundamentele misverstaan van God se genade. Kerklike dogma self moes hervorm word. Hoewel die teoloë van die Middeleeue baie oor genade gepraat het, was hulle verstaan daarvan, het Luther gekla, niks anders as 'n subtiele vorm van die Pelagianisme waarteen Augustinus 'n duisend jaar van te vore geveg het nie. Vir die Katolieke Kerk het ons regverdiging berus op ons heiligmaking en kon ons eers regverdig verklaar word nadat die proses van heiligmaking in ons lewe voltrek is. Die reformatore het geleer dat ons regverdiging nie afhanklik is van ons heiligmaking nie en die paradoksale gedagte gehandhaaf dat ons tegelyk geregverdig en sondig is voor God (simul iustus et peccator), wat vanuit 'n katolieke perspektief 'n kontradiksie in terme was. Daar is geen meriete, gebaseer op goeie dade teenoor ons naaste, wat ons regverdig voor God nie, dit geskied deur geloof alleen (Capetz: 2010:119).

Daar het met die Reformasie 'n breuk ontstaan met die skolastiese natuurgenade $^{8}$ skema van die Rooms-Katolieke Kerk, wat my insiens 'n nuwe

8 Sien Meulenman, GE (1967) Natuur en Genade, in Protestantse Verkenning na Vaticanum II. Berkof, $\mathrm{H}$ (eds.) pp.65-88; vir 'n oorsig van die natuur-genade onderskei in tradisionele en nuwe katolieke teologie en hoe dit deur Gereformeerde teoloë soos Bavinck en Berkhouwer in gesprek gebring word met die sonde-genade onderskeid eie aan Gereformeerde teologie. Die navorsing maak duidelik dat die verskil in beskouing natuur-genade dikwels gesien word as die grondverskil tussen die Rooms-Katolieke Kerke en Reformatoriese kerke. Die konklusie uit die bestudering van kerklike dokumente van die Konsilie van Trent en die Tweede Vatikaanse Konsilie is die vertaan van die erfsonde as die einde van bo-natuurlike kwaliteite van die mens wat hom of haarself in staat stel om God se wil te doen. Daar word aangetoon dat by Trent die gevalle mens ook sonder die genade nog vry is om die goeie te doen. By die Eerste Vatikaanse Konsilie word die geloof gesien as 'n vrye daad van die mens. Die wese van die erfsonde word gesien as die afwesigheid van God se heilsmakende genade. Die afwesigheid hiervan stel die mens skuldig voor God. Sonder die genade is die mens nie in staat tot bo-natuurlike goeie werke nie. Die samewerking tussen die genade en vrye wil bepaal die genadeleer van die Katolieke kerk. Die probleem is dat genade as bonatuurlik gesien word. Die genade stel die mens in staat om die bo-natuurlike te doen. Die punt is dat wanneer natuur en genade as twee teenoorgestelde pole teenoor mekaar gedink word, die koöperatiewe of samewerkingsbeginsel daarin opgesluit is wat al die ander dimensies van teologie bepaal. Die hart van die Reformasie word opgesom dat die wese van die mens behoort in 'n verbondsverhouding. Hierdie verbondsrelasie is so bepalend dat jy teologies nie meer sinvol oor die mens kan dink as hierdie relasie nie as vertrekpunt geneem word nie. Al moontlikheid is om nie natuur-genade, maar sonde-genade teenoor mekaar te stel. Vir Bavinck staan genade nie teenoor die natuur 
relasionele ontologie en 'n nuwe verstaan van transendensie impliseer. Anders as die Katolieke Kerk wat transendensie ingetrek het in 'n natuurbo-natuur skema, sou ons kon praat van 'n (wet-) sonde-genade skema. Hiermee vind 'n verskuiwing plaas van 'n essensialistiese ontologie na 'n relasionele ontologie. Wat sondig en immoreel is, val nie noodwendig saam met die natuur-bo-natuur (genade) skeiding nie. Die doel van die res van die artikel is om die implikasies van die sonde-genade skema in Gereformeerde teologie vir ons nadenke oor menslike seksualiteit te probeer uitwys. Daar sal kortliks by Calvyn in die verband aangesluit word, terwyl die wet-sonde-genade onderskeid in die denke van iemand soos die bekende gereformeerde teoloog, Michael Welker veronderstel word. Ek is van mening dat Welker se wet $^{9}$-sonde ${ }^{10}$-genade ${ }^{11}$ teologiese

nie, maar teenoor die sonde. Die doel van die genade is nie om die natuur te verhef tot die bo-natuurlike orde nie, maar om die mens se verhouding tot God te herstel.

9 Welker se verstaan van die wet bevestig sy radikale omhelsing van pluralisme as samelewingsverskynsel. Die wet as eerste gestalte van God se openbaring, balanseer volgens Welker die assosiatiewe en sistemiese dimensies van pluralisme deur in geregtigheids-, barmhartigheids-, en kultiese kodes te differensieër. Die soeke na geregtigheid, die bewys van barmhartigheid aan die gemarginaliseerdes van die samelewing en die soeke na waarheid of God se wil (geloofskennis) deur die kultus in die publieke sfeer van samelewings, is vir Welker die kriteria in terme waarvan daar tussen goeie en slegte vorme van pluralisme onderskei kan word. Die wet in die Pentateug, maar veral ook die profete is volgens hom baie sensitief vir die sistematiese distorsie van die goeie orde in die samelewing. Die vroeë profete soos Amos en Hosea het baie duidelik gesien dat die misbruik van die wet en die kultus hand aan hand gaan met die genadelose uitbuit van armes. Dit was vir hulle duidelik dat alleen 'n wet wat die sistematiese beskerming van die armes en die swakkes insluit, die naam geregtigheid waardig is. Die ware aanbidding van God in die kultus geskied ook alleen indien dit geregtigheid en barmhartigheid teenoor mense insluit (2000:13). Die dimensies van pluralisme is nie vir Welker alleen in die wet nie, maar ook in die skeppingsorde ingebed (Welker 1995:20-30). Anders gestel: die wet het vir Welker nie alleen normatief-etiese implikasies nie. Die wet beteken vir Welker ook skepping. Skeppingskennis is vir Welker gedifferensieërde kennis van die werklikheid en volgens hom is alle wetenskappe nodig om die interrelasionele verhoudinge van die verskillende skeppingsfere te ontdek en te beskryf.

10 Volgens Welker leer die Bybelse tradisies ons dat die goeie wet van God deur die sonde magteloos gemaak word. Alle vorme van pluralisme is dus nie noodwendig goed nie. Die goeie wet van God kan met die beste bedoelings, onder die grootste naïwiteit, deur ingrypende moralismes en met diepgestempelde vroomheid pervers gemaak word. Die misbruik van die wet lê vir Welker daarin dat dit onder die mag van die sonde die skyn van geregtigheid, die skyn van barmhartigheid en die skyn van geordende kultiese Godsverhoudinge voorhou (Welker 1995:89-95).

11 Die kruisiging en opstanding van Jesus Christus, as die tweede gestalte van God se Woord, dui volgens Welker vir ons die grense van ons natuurlike kennis aan, en breek terselfdertyd vir ons 'n perspektief oop op God en die eindige aantal pluralistiese relasies wat vir ons in Christus gegee is en wat alleen deur die geloof toeganklik is 
skema ons kan help om eties ruimte te skep vir 'n pluraliteit van seksuele identiteite en oriëntasies, sonder om in etiese relativisme te verval. Vir iemand soos Welker moet daar'n openheid wees vir dit wat skeppingsmatig (wet) gegee is, maar moet daar terselfdertyd vanuit die (evangelie) met groot sorg onderskei word waar God se goeie skepping so verbuig word, dat ongeregtigheid geskied teenoor die weduwee, die wese, die vreemdeling en gemarginaliseerdes. Die ervaring van uitsluiting wat die LGBTQI gendergroepe binne 'n normatiewe manlike kultuur beleef, tel vandag in die etiese gesprek rondom seksualiteit as deel van dié samelewingsgroepe waarteen ongeregtigheid gepleeg word (Ellison 2012:8-11).

Ons sien dat die verhouding tussen wet-sonde-genade alreeds Calvyn se denke onderlê en dat dit hom in staat stel om insigte uit die wetenskappe en ander samelewingsfere in sy teologiese nadenke ernstig te neem. Dit is interessant dat in historiese navorsing onder leiding van Don Browning oor hoe Calvyn die Rooms-Katolieke wetgewing rondom seks, die huwelik en familie in Geneva hervorm het, die natuurwet, 'n belangrike rol in sy denke bly speel het. ${ }^{12}$ Calvyn se denke oor seks, die huwelik en familie is

(Welker 1997:165). Vir Welker beteken geloof in Christus kennis van God en die "in-sien" van die regte verhouding tussen die verskillende differensiële sfere van die werklikheid. Geloof in Christus beteken vir Welker die bevestiging, maar dan ook die relativering van God se wet. Die kruisiging van Jesus is vir hom die bewys dat die religieuse-, politieke, en regsisteme van 'n samelewing kan korrupteer en dat ook die morele diskoers en publieke opinie van 'n hele kultuur deur die mag van die sonde misbruik kan word. Jesus word immers in die naam van twee regsisteme, naamlik die Romeinse en Joodse reg, gekruisig. Hy sterf ook in die naam van die politieke mag en publieke opinie van die dag. Die opstanding dui ten diepste op die oorwinning van die mag van die sonde en die moontlikheid van nuwe gemeenskap tussen die differensiële sfere van die skepping (Welker 1994:39-49).

12 In 'n voorwoord van die die boek deur Witte, J \& Kingdon, RM (2005), Sex, marriage, and family in John Calvin's Geneva (Vol. 1), Courtship, engagement, and marriage, wat 'n historiese studie is van hoe Calvyn die stad Geneve hervorm het om weg te beweeg van die Rooms-Katolieke Kanoniese Wet (Canon Law), kom Don Browing tot 'n paar baie belangrike insigte rondom Calvyn se beskouing van seksualiteit, die huwelik en die veranderende posisie van vroue en kinders. Ons sien vir Calvyn, Beza en ander volgelinge is "verlowing" (engangement) amper net so 'n ernstige kontrak en verbond as die huwelik self, maar dat hofmakery (courtship) 'n nuwe klem ontvang in die proses oppad na 'n huwelik. Vir Calvyn was wedersydse instemming van albei partye (soos met "canon law"), maar veral ook wedersydse aantrekkingskrag, ononderhandelbaar vir die huwelik. 'n Romantiese vonk was vir Calvyn essensieël vir 'n goeie huwelik en hofmakery was die tyd om dit te ontdek. Wat veral verras uit die navorsing is dat natuurwet, anders as by Luther, 'n groot rol speel in Calvyn se denke oor seksualiteit en die huwelik. Die natuurwet moet egter altyd weer in die lig van die evangelie relativeer word. 
multidimensioneel en funksioneer op verskillende vlakke. Sy teologie bied die raamwerk vir die ander dimensies van denke, maar het beslis nie die ander dimensies van sy denke volledig gedetermineer nie. Calvyn is diep bewus daarvan dat in terme van geregtigheidsvraagstukke ongelowiges dikwels tot dieselfde konklusies as gelowiges kom.

Browning (in Witte, J \& Kingdon, RM; 2005) meen Calvyn is 'n goeie kandidaat om te ontgin vir die dialoog tussen reg, religie, en ander wetenskaplike dissiplines. Die huwelik staan vir Calvyn byvoorbeeld sentraal, nie omdat dit 'n goddelike bevel is nie, maar omdat dit verskillende dimensies van die lewe integreer, wat goed is vir individue en die samelewing. Omdat Calvyn op die vlak van die natuurwet en die ekonomie dink, is hy baie bewus van die bio-ekonomiese voordele van die huwelik. Calvyn het geweet dat om die huwelikswet in Genève te skryf hy ook die insigte van die ongelowige wêreld rondom hom moet respekteer en in berekening bring. Hierdie insigte is egter altyd weer relativeer in die lig van die genade van God in Jesus Christus. Alreeds vir Calvyn staan die kerk voordurend voor die uitdaging om te onderskei wat van die skeppingsmatige (wet) ons omhels en wat ons afwys as 'n verbuiging van God se goeie wil. Sonde is vir Gereformeerdes dus nie sonder meer in die natuur gegee wat deur die genade tot 'n hoër vlak herstel of verhef moet word nie. Wat sonde is, moet in elke situasie van vooraf uitgemaak word. Die kerk kan dit eties net uitmaak in 'n interdissiplinêre ruimte waar die stemme van ander wetenskappe, wat besig is met die skeppingsmatige werklikheid, gehoor word.

Die spanning in seksuele etiek vandag kom myns insiens neer op dit wat natuurlik gegee is en wat mense as natuurlik ervaar, en die vraag op watter punt word dit wat as natuurlik ervaar word, beskou as immoreel en onaanvaarbaar. Homoseksuele persone sal dikwels aanvoer dat die kerk hulle moet aanvaar omdat "God hulle so gemaak het", waarop ander Christene sal antwoord, dat pedofilie ook vir baie mense iets natuurlik is wat in hulle opkom, maar ons dit tog almal afkeer as immorele gedrag. In die hantering van die spanning van wat natuurlik gegee is en wat eties goed en aanvaarbaar is, het ons teologiese kriteria nodig wat voortkom uit ons diepste Gereformeerde teologiese identiteit wat gebreek het met die synsontologie van die Rooms-Katolieke Kerk, en wat dink vanuit 'n relasionele ontologie, waarin daar tegelyk 'n omhelsing is van die 
verskillende skeppingsfere van die werklikheid en die soeke na geregtigheid teenoor weerlose en gemarginaliseerde mense die swaarste weeg.

Seksuele etiek wat binne 'n relasionele ontologie bedink word, word myns insiens 'n soeke na geregtigheid. Die onderskeid tussen beter en slegter vorme van seksualiteit gaan nie bepaal word deur dit in tekste of historiese praktyke af te lees nie. Gereformeerdes sal moet vra na ons diepste teologiese identiteit en van daaruit keuses maak. Wanneer daar byvoorbeeld oor selfdegeslagverhoudings nagedink word, kan ons argumente ook nie wees dat God my bloot so gemaak het nie. Ons seksuele identiteit word deur 'n baie groter en dieper identiteit onderlê. Ons identiteit "in" Christus Jesus.

Enige teologiese begronding vir seksuele etiek vanuit 'n Gereformeerde perspektief moet in die evangelie van God se verkiesende genade gegrond wees, en nie in wat ons dink natuurlik is nie. In ons nadenke oor seksualiteit moet ons die feit dat ons self in Christus uit genade deur geloof op grond van die Skrif gered is (solus Christus, sola gratia, sola fide, sola scriptura) as vertrekpunt neem. Ons moet in ons basiese nadenke oor seksualiteit onthou dat ons nie "van nature" kinders van God is nie. Ons is God se kinders op grond van God se verkiesende genade. In terme van Paulus se taal is ons self vandag heidene wat uit genade gered is. Ons is gekies en aangeneem. Ons is ingeplant in die volk van God, ons is dit nie "van nature" nie. God se verkiesende genade eerder as 'n Darwinistiese fokus op prokreasie, moet ons nadenke oor die seksualiteit, die liggaam en gender onderlê. Kortom, ons etiek ten opsigte van menslike seksualiteit, moet gegrond wees in ons ekklesiologie en die doop. Die eerste sinode in Jerusalem het gekonkludeer dat ons identiteit nie primêr bepaal word deur of ons Jode of heidene is nie. Ons identiteit word bepaald deur die feit dat ons "in Christus" is. Meer as dit: alle ander vorme van identiteit word hierdeur relativeer.

In sy boek, Sexuality and the Christain Body: their way into the Triune God (1999) gee Eugene F. Rogers 'n beskrywing van wat hy die standaard argument vir immoraliteit deur die eeue noem. Hy noem dit standaard, omdat deur die hele geskiedenis daar vir die morele minderwaardigheid van 'n sekere groep of klas mense geargumenteer is op grond van dit wat natuurlik is. So 'n standaard-argument geld steeds vandag vir vroue in die Midde-Ooste. Vroue word gesien as "van nature" seksueel losbandig en daarom is sosiale grense en reëls nodig om hulle in bedwang te hou (Rogers: 
1999:56). Volgens hom was die standaard-argument ook van toepassing op swart mense in die suide van Amerika gedurende die slawerny en rassesegregrasie in Suid-Afrika. Rogers toon oortuigend aan hoe daar in die seksuele diskoers wat in die tyd gevoer is, veronderstel is dat swart mans 'n onversadigbare drang het vir wit vrouens. Swart mense is oor die algemeen as seksueel meer losbandig as witmense beskou. In albei gevalle is seksuele dekadensie verbind aan dit wat "van nature" gegee is (1999:56).

Rogers argumenteer dat in die Ou en die Nuwe Testament geld dieselfde vir heidene. Die heidene was beskou as van nature meer blootgestel aan immoraliteit en seksueel afwykende gedrag. Paulus gee in Romeine $1^{13}$ 'n standaard Joodse beskouing van die heidene se moraliteit. ${ }^{23}$ In die plek van die heerlikheid van die onverganklike God stel hulle beelde wat lyk soos 'n verganklike mens of soos voëls of diere of slange. Daarom gee God hulle aan die drange van hulle hart oor en aan sedelike onreinheid, sodat hulle hulle liggame onder mekaar onteer. Dit is hulle wat die waarheid van God verruil vir die leuen. Hulle dien en vereer die skepsel in plaas van die Skepper, aan wie die lof toekom vir ewig. Amen ${ }^{26}$ Daarom gee God hulle oor aan skandelike drifte. Hulle vroue verander die natuurlike omgang in 'n teen-natuurlike omgang. ${ }^{27} \mathrm{Net}$ so laat vaar die mans ook die natuurlike omgang met die vrou en brand van begeerte vir mekaar. Mans pleeg skandelikhede met mans en bring oor hulleself die verdiende straf vir hulle perversiteit.

Die punt om in te sien, is dat dit 'n beskrywing is van wie die heidene van nature is (Rogers 1999:58). Hulle is van nature korrup en ontaard. Daarom doen hulle dinge wat "teen die natuur is". Ons sien hier hoe die standaard argument toegepas word. Die argument is deur die eeue op Jode, vroue, swart mense en vele ander verwerplike groepe toegepas. In ons tyd veral op homoseksuele mense. Dit is belangrik om te verstaan dat heidene nie net onnatuurlike dinge doen nie, maar dat hulle natuur hulle immoreel en minderwaardig maak.

As ons dit verstaan, verstaan ons die morele skok van God se genade in Galasiërs 3:26-29. ${ }^{26}$ Deur hierdie geloof in Christus Jesus is julle nou almal kinders van God, ${ }^{27}$ want julle almal wat deur die doop met Christus verenig

13 Alle teksverse is aangehaal uit: Die Bybel, 1983-vertaling. Bybelgenootskap van SuidAfrika. 
is, het nou deel van Christus geword ${ }^{28}$ Dit maak nie saak of iemand Jood of Griek, slaaf of vry, man of vrou is nie: in Christus Jesus is julle almal één. ${ }^{29}$ En as julle aan Christus behoort, is julle ook nakomelinge van Abraham en erfgename kragtens die belofte van God.

Volgens Rogers is Paulus besig om groepe wat van nature nie bymekaar hoort nie, met mekaar te meng. Dit gaan selfs verder. Ons sien 'n mengsel van die moreel minderwaardige en met die moreel meerderwaardige. In die eerste eeu was slawe, vroue en heidene van nature moreel minderwaardig, veral in vergelyking met die manlike Jood as die hoogste natuurlike soort. Wat ons volgens Rogers in Galasiërs 3:28 lees is skokkend (1999:60). Dit gaan oor baie meer as bloot die regverdiging van die afskaffing van slawerny of genderverhoudings. Dit gaan oor die oorskryding van 'n bepaalde verstaan van moraliteit en heiligheid. Dit gaan oor die byeenbring van natuurlike groepe in Jesus Christus, groepe wat of heiligheid of korrupsie en dekadensie verteenwoordig.

Die skok gaan baie dieper. Later in Romeine 11:24 gebruik Paulus weer die konsep para phusin (teen natuur), maar hierdie keer is dit nie van toepassing op homoseksualiteit nie, maar op God self (Rogers 1999:65). Paulus beskryf God se inplanting / inenting van die heidene in die boom van Israel as "teen die natuur". Paulus neem para phusin van Romeine 1 en stel dit parallel aan God se genade in Christus Jesus. Die heidene tree "onnatuurlik" op, en God in sy genade doen iets net so "onnatuurlik". God transendeer die kategorieë van natuurlike morele groepe om een liggaam van Christus te skep.

Natuurlikis Paulus niein die Romeinebriefbesig om selfdegeslagverhoudings te legitimeer nie. Wat Paulus doen is om te wys hoe die genade van God die standaardargument, die argument dat sekere mense van nature moreel minderwaardig is, ondermyn (Rogers 1999:65). Dit is natuurlik nie al wat gesê kan word nie, maar dit sal Gereformeerde kerke in Suid-Afrika met 'n blindekol rondom in-en-uitsluiting, soos wat met kritiek op apartheid ontbloot is, in die gesprekke rondom seksualiteit goed doen om ons te herinner dat God vreemde dinge doen, wanneer dit kom by "natuur" en wat vir ons "natuurlik" lyk. Dit lyk of God teen die natuur handel, om ons vooroordele van wat natuurlik en onnatuurlik is, uit te wis. In die debat rondom selfdegeslagverhoudings, moet ons "natuur" in terme van 
God se verkiesing herdink. God het die heidene, wat van nature seksueel afwykend opgetree het, ingeplant in die stam van Israel. God oorskry die standaard-argument van die Jode, en tree in die sin teen-natuur-lik op. Sulke handelinge van die lewende God, moet ons vir 'n oomblik tot stilstand laat kom, wanneer ons nadink oor die intiemste verhouding van homoseksuele mense wat ingedoop is in die liggaam van Christus.

Uiteindelik het die kerk op verskillende punte ontdek dat mense se identiteit in Christus polities en eties meer betekenisvol is as die kulturele aanvaarding van slawerny of die onderdrukking van vroue binne 'n patriargale kultuur, wat natuurlik die Bybel self onderlê. Het dit nie tyd geword dat ons die homoseksuele identiteit wat ons as biologiese en kulturele identiteit onderskei, ook relativeer in die lig van ons doop in Christus in nie? Is die identiteit van 'n homoseksuele gelowige nie eerstens die van iemand wat in Christus is, en nie iemand wat homoseksueel is nie? Terwyl 'n homoseksuele persoon homoseksueel bly (wet of skepping), in Christus Jesus, moet ons uiteindelik vra, wat weeg die swaarste: ingelyf in Christus, deur die Heilige Gees en die doop, of sy of haar seksuele oriëntasie?

Die kerk moet eerlik wees en erken: ons dink lankal nie meer oor seksualiteit in terme van prokreasie en biologie nie. Die seksuele etiek wat vir eeue gebou is op 'n androgene, patriargale antropologie en vir eeue vanselfsprekend gegee is, is besig om te verbrokkel. Ons moet oor begeerte en seksualiteit dink in die lig van die evangelie, en meer spesifiek vanuit ons ekklesiologie. Gelowiges moet verstaan dat hoe daar oor die kerk as liggaam van Christus gedink word, ook bepaal hoe ons oor die liggaam van die homoseksuele persoon dink en nie andersom nie.

\section{Seks as die liggaam se genade}

Hoe moet ons die uitleef van ons liggaamlike passies en seksualiteit in die lig van ons identiteit in Christus en as deel van die liggaam van Christus dink? In sy wonderlike meditasie The Body's Grace (2002) help Rowan Williams ons om die liggaam self as 'n voertuig van genade te sien. Volgens Williams is ons nêrens meer weerloos as tydens seks nie. Die wonder van seks is dat dit in hierdie momente is wat ons onsself deur ander se oë leer ken as begeerlik en 'n gebeurtenis van vreugde. 
Williams beskryf genade as volg:

Grace, for the Christian believer, is a transformation that depends in large part on knowing yourself to be seen in a certain way: as significant, as wanted. The whole story of creation, incarnation, and our incorporation into the fellowship of Christ's body tells us that God desires us, as if we were God, as if we were that unconditional response to God's giving that God's self makes in the life of the Trinity. We are created so that we may be caught up in this, so that we may grow into the wholehearted love of God by learning that God loves us as God loves God (Williams 2002:309).

Genade is vir Williams die transformasie van die self wat in 'n groot mate afhanklik is daarvan dat jy weet dat jy op 'n sekere wyse gesien word: as betekenisvol, as begeerlik. Die hele Christelike verhaal vertel, volgens hom dat God ons begeer, asof ons God is, asof ons die onvoorwaardelike respons is op God se genade, wat God self in die lewe van die Triniteit skenk. Ons is geskep om opgeneem te wees hierin, sodat ons kan ingroei in die liefde van God deur te leer dat God ons liefhet soos God God liefhet. Die lewe van die Christelike gemeenskap het volgens Williams die taak om mense te leer om hul verhoudings so te orden dat hulle hulself sal sien as begeerlik, as gebeurtenisse van vreugde.

Die ervaring van my liggaam as genade deur die oë van die ander, is vir Williams moontlik indien my liggaam, ons liggame opgeneem is in die gemeenskap van die Triniteit. Daar moet wedersydse liefde en egte gemeenskap wees. Wanneer wedersydse kenosis teenwoordig is, kan ons seksualiteit ervaar as genade, die liggaam se genade. Williams skryf:

We find in sexuality an experience of grace, the body's grace: For my body to be the cause of joy, the end of homecoming for me, it must be there for someone else, must be perceived, accepted, nurtured. And that means being given over to the creation of joy in that other, because only as directed to the enjoyment, the happiness, of the other does it become unreservedly lovable. To desire my joy is to desire the joy of the one I desire: my search for enjoyment through the bodily presence of another is longing to be enjoyed in my body (Williams 2002:320). 
Seksualiteit is dus ingeknoop in ons verhouding met die drie-enige God. Eros (begeerte) kan net ervaar word deur agape (self-prysgawe). Werklike liefde word alleen ervaar wanneer my vreugde tot volheid kom oorgegee aan die vreugde van die ander. Ons seksuele eenheid moduleer dus die lewe van die Triniteit. Die liefde van die Seun word geskenk aan die Vader en die Vader beantwoord dit deur die Heilige Gees. Die een word leeg in die ander, 'n ewige vloei van self-leegmakende liefde, heen en weer, heen en weer; 'n golf van kenosis en liefde. Geskenke gegee en ontvang, heen en weer, Vader, Seun en Gees wat mekaar telkens ontdek as gebeurtenisse van vreugde (Williams 2002:321).

\section{Samevatting}

Om eties te dink oor menslike seksualiteit binne die skema van wet-sondegenade van goeie reformatoriese teologie stel ons voor die uitdaging om die pluraliteit van die skeppingsmatige werklikheid te omhels, terwyl ons saam met ander wetenskappe in die lig van die evangelie probeer uitmaak waar ongeregtigheid teenoor die ander geskied. Die teoloog Walter Brueggemann beklemtoon: "In biblical faith the doing of justice is the primary expectation of God" (in Ellison 2012:9). Die soeke na geregtigheid is vandag multidimensioneel, tog bly die vraag na erotiese geregtigheid, grootliks uitgesluit uit die sosiale agenda van kerke. Om te vra na erotiese geregtigheid, klink nie vir ons baie Christelik of belangrik nie. Christelike kerke, wat steeds vasgevang is in 'n patriargale gender antropologie, vind dit moeilik om eerlik te praat oor seks en wat dit vir en aan mense doen. Hoewel daar aandag gegee is aan die veranderende rol van vroue, die sonde van homoseksualiteit en seks buite die huwelik, toon die kerk min insig in die groter vraagstukke rondom seksualiteit as geheel binne die samelewing waarbinne ons woon.

Die kerk sit na my oordeel met uitgediende aannames van gender, seksuele verskille en familiepatrone, wat geld as seksuele sonde. Die baie maal misplaaste obsessie met homoseksualiteit moet myns insiens verskuif na kwessies soos gender, seksuele onderdrukking en die seksuele geweld in ons huise en samelewings. Verder vra 'n eerlike etiese soeke na geregtigheid in ons seksuele verhoudings dat ons vra met wie ons praat en na wie ons luister. Wêreldwyd is 'n magsverskuiwing aan die gang waarin vroue en 
LBGTIQ persone van alle kleure en klasse op 'n regverdige wyse wil deel hê aan die vernuwing van die geestelike tradisies waarvan hulle deel is.

\section{Bibliografie}

Barnes, C 2010. "Thomas Aquinas on the Body and Bodily Passions”. In The Embrace of Eros: Bodies, Desires, and Sexuality in Christianity. Kamitsuka, M.D., (eds.). Minneapolis: Fortress Press. pp. 83-97.

Capetz, PE 2010. "Reformation Views on Celibacy: An Analogy for Gay Protestants Today". In The Embrace of Eros: Bodies, Desires, and Sexuality in Christianity. Kamitsuka, M.D; (eds.). Minneapolis: Fortress Press. pp.115-131.

Coakley, S 2012. "Gregory of Nyssa”. In The Spiritual Senses: Perceiving God in Western Christianity. Gavrilyuk P.L. \& Coakley, S. (eds.). Cambridge: Cambridge University Press. pp. 36-55.

Cortez, M 2010. Theological Anthropology - a Guide for the Perplexed. London: T \& T Clark.

Ellison, MM 2012. Making Love Just: Sexual ethics for Perplexing Times. Minneapolis: Fortress Press.

Kamitsuka, MD (eds). 2010. The Embrace of Eros: Bodies, Desires, and Sexuality in Christianity. Minneapolis: Fortress Press.

Lootens MR 2012. "Augustine”. In The Spiritual Senses: Perceiving God in Western Christianity. Gavrilyuk PL \& Coakley, S (eds.). Cambridge: Cambridge University Press. pp.56-70.

Meuleman, GE 1967. "Natuur en Genade”. In Protestantse Verkenning na Vaticanum II. Berkof, H (eds.). Breedevoort: Gravenhage Boekencentrum. pp. 65-88.

Naphy, W 2006. Born to be Gay: a History of Homosexuality. Stroud: Tempus.

Ranke-Heinemann, U 1991. Eunuchs for the Kingdom of Heaven:Women, Sexuality and the Catholic Church. New York: Penguin Books. 
Robinson, V \& Richardson, D (red.) 2015. Introducing Gender \& Women's Studies (Fourth Edition). New York: Palgrave Macmillan.

Rogers, EF 1999. Sexuality and the Christian Body: their way into the Triune God. Oxford: Blackwell Publishers Ltd.

Salzman, TA \& Lawler MG 2012. Sexual Ethics: A Theological Introduction. Washington, DC: Georgetown University Press.

St. Augustine. 2004. The Confessions. Massachusetts: Hendrickson Publishers.

Vardy, P 2009. The Puzzle of Sex. London: SCM Press.

Welker, M 1995. Schöpfung und Wirklichkeit. Neukirchener-Vluyn: Neukirchener.

Welker, M 1994 Auferstehung. Glauben und Lernen (9). pp. 39-49.

Welker, M 1997. Wort und Geist. Jesus Christus als der Mitte der Schrift: Studien zur Hermeneutik des Evangeliums. Berlin / New York: Walter de Gruyter. pp. 159-169.

Welker, M 2000. Christianity and Structured Pluralism. Unpublished Paper. US.

Wiley, T.; 2010. "Humanae Vitae, Sexual Ethics, and the Roman Catholic Church". In The Embrace of Eros: Bodies, Desires, and Sexuality in Christianity. Kamitsuka, MD (eds.). Minneapolis: Fortress Press.

Williams, R 2002. “The Body's Grace”. In Rogers EF (eds.), Theology and Sexuality: Classic and Contemporary Readings. Oxford: Blackwell, pp. 309-321.

Witte, J \& Kingdon, RM 2005. Sex, Marriage, and Family in John Calvin's Geneva (Vol. 1) courtship, engagement, and marriage. Grand Rapids Michigan: William B. Eerdmans Publishing Company. 